\author{
RYSZARD KAMIŃSKI
}

\title{
Non-Financial Reporting in the Light of International Regulations and EU Directives
}

\section{Introduction}

The contemporary model of company reporting is evolving with changes in the business environment. Increasingly, entrepreneurs get information not only about the economic aspects of companies' operations but also about social and environmental aspects. The disclosure of such information is usually done through annual reports. The guidelines exist for the production of such reporting, and legal requirements can be found in some European countries.

The EU Member States and the European Union have a significant contribution to the development of company reporting standards. On 16 April 2013, the European Commission adopted a proposal for a directive enhancing the transparency of certain large companies on social and environmental matters. The purpose of Directive 2013/34/EU was to increase EU companies' transparency and performance on environmental and social matters, therefore contributing effectively to long-term economic growth and employment. ${ }^{1}$ The companies concerned will need to disclose information on policies, risks and results as regards environmental matters, social and employee-related aspects, respect for human rights, anti-corruption and bribery issues, and diversity on the boards of directors. Directive 2013/34/EU was amended by Directive 2014/95/EU of the European Parliament and of the Council as regards disclosure of non-financial and diversity information by certain large undertakings and groups. ${ }^{2}$ From 2018, around 6000 large organisations in Europe will

1 Official Journal of the European Union L 182/19 2013. Directive 2013/34/EU of The European Parliament and of The Council of 26 June 2013 on the annual financial statements, consolidated financial statements and related reports of certain types of undertakings, amending Directive 2006/43/EC of the European Parliament and of the Council and repealing Council Directives 78/660/EEC and 83/349/EEC.

2 Official Journal of the European Union, L 330/1 2014. Directive 2014/95/EU of The European Parliament and of the Council of 22 October 2014 amending Directive 2013/34/EU as regards disclosure of non-financial and diversity information by certain large undertakings and groups. 
start reporting non-financial information for the financial year 2017 under the EU NonFinancial Reporting Directive. The Directive requires organisations to include in their annual report a non-financial statement describing the impact posed by their operations to matters such as the environment, employees, social issues, corruption, human rights and bribery, and how they manage the principal risks that are involved. These companies also have to disclose the diversity policy for their administrative, management, and supervisory boards. This Directive represents the most significant EU legislative initiative in respect of such environmental, social and governance disclosure in nearly a decade and is likely to have a significant impact on the non-financial information reporting of many of the companies affected. The European Commission also published the Guidelines to the Directive on 26 June 2017 to support companies in the preparation of this non-financial statement. ${ }^{3}$

The observed trends of non-financial reporting concepts has inspired the writing of this article. The aim of the paper is to present and evaluate the non-financial reporting system, focusing in particular on the European Union. The aim of the paper determined the content and sequence of the main issues tackled with in the text. These include:

1) The characteristics of the essence and concepts of non-financial reporting.

2) A short description of international standards on non-financial reporting.

3) A presentation of EU regulations on non-financial reporting.

4) A presentation of EU guidelines to support companies in the preparation of this non-financial statement.

The study included companies obliged to prepare statements in accordance with UE regulations. The provisions quoted in the paper were enforced on 31 December 2017. The basic source material used in the work was literature on non-financial reporting and legal acts. The work methods that were used include a descriptive analysis method and a comparative method.

\section{The Essence of Reporting Non-Financial Information}

The system of reporting should provide different reports for different users in accordance with their expectations. The information provided through these reports should allow the correct interpretation of the business information. To achieve this requirement, the essential parts of the system are both financial information and non-financial information. The term "non-financial information" is often used to refer to data on environmental issues, but in reality it covers a much broader area. Nonfinancial information involves issues related to: sustainability, corporate responsibility, the environment, social and governance issues, ethics, human capital, health. Non-financial information is

3 Guidelines on non-financial reporting(methodology for reporting non-financial information) (2017/C 215/01), Official Journal of the European Union C 215/1, [access: 5.7.2017]. 
typically indirectly correlated with an organization's financial performance and outlook, especially when assessed over time. Moreover, nonfinancial performance also impacts the tangible asset value and can be tied to intangible assets, including brand reputation, intellectual capital and an organization's market value. Company managers and external stakeholders (including investors) increasingly consider non-financial information in their decision-making as the link between tangible and intangible assets. The organizations need detailed insight into their financial, social and environmental impacts, both externally and internally. These could include human rights impacts within their supply chain, carbon dioxide emissions from the company's operations, or environmental impacts as a consequence of the downstream use of their products. As companies get more detailed insights into these impacts, they also start to manage them, driven by the fact that "what gets measured gets managed". 4

It is assumed that non-financial material information should involve not only historical data (i.e. financial performance data) but also forward-looking information including projections or forecasts. In the literature the view is often encountered that non-financial reports should disclose the information that would enable investors and other stakeholders to run models or make their own predictions about the future value creation potential of the organization. However considering the risk of providing proprietary information to competitors, companies would normally not be required to disclose sensitive information related to, for example, trade and R\&D programmes. With the proviso that if material information is not disclosed because of perceived competitive harm, this fact and the reasons for it will be noted in a report. ${ }^{5}$

In this context, it is reasonable to compare the characteristics of financial and nonfinancial information.

- Financial information relates to cash flows and the results and (balance sheet) positions associated with them. The information has a direct link with the financial registration system and can be historical or prospective. Financial information is expressed in monetary units and can be measured exactly.

- Non-financial information relates to all information other than the financial information that does not have a direct link with a financial registration system. Often there is no comprehensive registration system. Insofar as there are internal procedures for risk management and collecting information, these will as a rule contain fewer safeguards for the reliability of the information.

4 The road to reliable nonfinancial reporting, Ernst\&Young 2016, http://www.ey.com/Publication/ vwLUAssets/EY-ccass-road-to-reliable-nonfinancial-reporting/\$FILE/EY-ccass-road-toreliable-nonfinancial-reporting.pdf [access: 4.11.2016].

5 Financial ws Non-Financial Information, Materialitytracker, 2016, http://www.materialitytracker.net/standards/financial-vs-non-financial-information/ [access: 20.01.2016]. 
It should be emphasized that the nature of non-financial information can be qualitative or quantitative:

- Quantitative means that the information is numerical. The information is capable of being expressed in numbers or figures, for instance in quantities or periods. Quantitative non-financial information is akin to financial information, but is usually of a less uniform nature. Often it is measurable and an indirect link can be made with a (financial) registration system.

- Qualitative information is of a descriptive nature. Pertinent examples are performance, the functioning of systems and processes, physical characteristics or compliance with codes of conduct. Usually there is no comprehensive registration system for this information, nor a generally accepted frame of reference, or standardised units. Qualitative information can often be translated into quantitative information by applying a quantitative framework of standards, in the form of performance data. As a rule this will lead to a certain degree of simplification. ${ }^{6}$

Non-financial information can be presented in different ways. Usually it is combined with reporting of financial information. There are three forms of presentation:

- In combination with a financial statement intended for general purposes, or prepared for a specific purpose. The information forms part of the financial statements or the information is enclosed in a separate report.

- This can be the directors' report accompanying financial statements. It contains a commentary on the relevant information of assets and the company's financial position, including the evaluation of the effects and the identification of risk factors with the described threats. This also contains non-financial data, including information on environmental issues and employment.

- In a stand-alone separate report, not in combination with a financial report. Wellknown examples are corporate social responsibility reports and environmental reports. They do contain financial information as well, but the emphasis is on the non-financial information. ${ }^{7}$

In the practice of companies there are different ways to define, prepare, and disseminate non-financial reports. Francesco Perrin examined the reports of 90 companies from the 150 included in the Ethical Index Euro. ${ }^{8}$ Based on the results of these studies, he identified five distinctive features which represent the common starting point for distinguishing non-financial reports from other documents:

6 Non-f inancial information in progress. A guide to the reporting and assurance of non-financial information in the public sector, Nivra, 008 Royal NIVRA Amsterdam, https://www.nba.nl/ Documents/Vaktechnisch-thema/MVO/NFI-wegwijzer-Engelse-versie.pdf. p.10-11 [access: 2.01.2016].

7 Non-financial information in progress, op. cit. p. 15.

8 F. Perrin, The Practitioner's Perspective on Non-Financial Reporting, California Management Review, vol. 48, no. 2, Winter 2006, pp. 75-78. 
- Complementarity with Annual Financial Report.

Non-financial reports are published to complete the corporate economic portrait by adding a social and environmental dimension. Social, environmental and sustainability reports frequently follow the same time schedule and structure as annual reports, and they are often updated quarterly. F. Perrin noted that many companies progressively integrate different documents. They usually start with an environmental report, shift to producing a social and environmental report, and then publish a sustainability report, which integrates social, economic, and environmental issues into a unique document.

- Qualitative information and quantitative data are contained in non-financial reports. The quantitative data allow readers to do temporal or spatial comparative assessments, and the qualitative information enhances the communicative potential. Usually, reports are structured in two main sections. The first one describes the firm's programs qualitatively and the second one summarizes programs, activities, and investments from a quantitative point of view.

- Outside Orientation. Non-financial reports usually are produced as a direct result of an accountability process, which is the process of becoming an open and responsive organization that is able to balance the interests of various stakeholders. Therefore, these reports are expressly outside-oriented, aimed at sharing information systematically about the exchange relationships between companies and their stakeholders. The results indicate that the reports are expressly stakeholder-oriented.

- Stakeholders are involved in the process dimension of non-financial reports. Companies tend to focus on ongoing interactions with stakeholders and stress the exchange of ideas that has allowed companies to better understand stakeholders and their interests. This means that stakeholders' needs and requests are taken into account in the report.

- Expected outcomes. These are strengthening "the strategic reporting aptitude" and "the internal reporting aptitude". The implementation of the first task increases opportunities to check corporate strategic positioning, redefine their mission and values, evaluate progress, reorient corporate action, and manage relationships with stakeholders. The expectation of strengthening "the internal reporting aptitude" entails that reports are strictly tied to organizational objectives, such as redefining responsibilities and tasks across divisions within the company, enhancing collaborations, identifying synergies among divisions and corporate functions through the systematization of dispersed data and information. 


\section{Standards of Reporting Non-Financial Information}

Unfortunately, in practice, non-financial reports are often incomparable and this prevents stakeholders from making decisions regarding this particular area. This problem is exacerbated by the fact that companies are free to decide what information to disclose and how to do it. Therefore, they often avoid presenting information that is not completely positive, and try to present all information in the best possible light. In order to improve the quality and increase the comparability of reports consisting of non-financial information, work commenced on the implementation of standards in this area as early as the 1970s. Today in practice, there are different standards, recommendations and guidelines. Companies can therefore base their reports on a variety of proposals for non-financial reporting systems developed by many organisations. Among them there are proposals of the following organisations:

- United Nations Global Compact (UNGC),

- Organization for Economic Co-operation and Development (OECD),

- International Labour Organization (ILO),

- Global Reporting Initiative (GRI),

- International Integrated Reporting Council (IIRC),

- Sustainability Accounting Standards Board (SASB),

- European Federation of Financial Analysts Societies (EFFAS),

- standards and certifications: AccountAbility's AA1000 Standards and ISO 26000.

Launched in 2000, the United Nations Global Compact is a platform for businesses for the development, implementation and disclosure of responsible, and sustainable corporate policies and practices. The UNGC seeks to align business operations and strategies with ten universally accepted, guiding and overarching principles in the areas of human rights ( 2 principles), labour ( 4 principles), the environment ( 3 principles), and anti-corruption (1 principle). It assists private sector businesses in the management of increasingly complex risks and opportunities, and seeks to embrace, support and enact, within their sphere of influence, a set of core values in these areas. ${ }^{9}$

The Organization for Economic Co-operation and Development guidelines for multinational enterprises are a set of non-binding norms and rules for international enterprises. Their goal is to help these companies contribute positively to a better natural, social and economic environment. By transforming the impact of companies on society, these Guidelines aim to change the choice of investment by adding a completely new perspective - non-financial results..$^{10}$

9 TheTenprinciples, United Nations Global Compact, https:/www.unglobalcompact.org/ aboutthegc/ [available 20 January 2014]; EU Directive on disclosure of non-financial and diversity information. Achieving good quality and consistent reporting. Position Paper, Federation of European Accountants, march 2016, p. 6.

10 OECD Guidelines for Multinational Enterprises 2011 Edition, OECD Publishing, 2011. EU Directive on disclosure, op. cit. p. 8. 
In 1977, the International Labour Organisation adopted the ILO Tripartite Declaration of Principles concerning international companies and social policy (it was revised in 2000). ${ }^{11}$ The purpose of this Declaration was to encourage multinational companies to solve problems that may arise as a result of their activities in the host countries. This paper opts for an improvement in the situation on the local labour market, especially in countries with high levels of unemployment. The Declaration contains regulations concerning basic human rights, minimum wage, labour relations, working conditions, and health and safety.

The Global Reporting Initiative started publishing non-financial reporting guidelines in the 1990s to help organisations communicate about their impact on society and environment. Since inception, the GRI has gained major attention from companies and has become a worldwide reference for reporting. The latest (G4) version particularly focuses on issues related to materiality - it encourages companies to focus their communication on the most relevant topics related to their core business. ${ }^{12}$

The International Integrated Reporting Council was launched in 2010 with the objective of developing and promoting integrated reporting by businesses. Integrated reporting is a framework designed to change corporate communication to produce company reports that detail organisational undertaking. The IIRC believes that the implementation of the non-financial reporting directive should follow the underlying approach of the integrated reporting framework as this framework emphasises the connectivity of financial and non-financial information and highlights the key role that materiality has to play. By integrating financial with non-financial information, the aim is to make clear how value-relevant information fits into the operations of the undertaking and thereby help embed long-term decision making into the undertaking's management. ${ }^{13}$

The Sustainability Accounting Standards Board is a US not-for-profit organisation established in 2011 to develop and disseminate accounting standards dealing with social and environmental issues. A significant characteristic of the SASB is that the standards developed are intended to be consistent with the current US system of financial regula-

11 Tripartite declaration of principles concerning multinational enterprises and social policy, International Labour Office, Geneva 2006.

12 G4 Sustainability Reporting Guidelines, Reporting Principles and Standard Disclosures, Global Reporting Initiative, https://www.globalreporting.org/resourcelibrary/GRIG4-Part1-Reporting-Principles-and-Standard-Disclosures.pdf, [access: 2.03.2015]. G4 Sustainability Reporting Guidelines, Implementation Manual, Global Reporting Initiative, https://www.globalreporting. org/resourcelibrary/GRIG4-Part2-Implementation-Manual.pdf, [access: 2.03.2015]; EU Directive on disclosure, op. cit., p. 6.

13 The International $<I R>$ Framework, Integrated Reporting $(<\mathrm{IR}>)$, IIRC, http://www.theiirc. org/wp-content/uploads/2013/12/13-12-08-THE-INTERNATIONAL-IR-FRAMEWORK-2-1.pdf. [access: 23.09.2014]. Towards Integrated Reporting. Communicating Value in the 21st Century, IIRC, http://theiirc.org/wp-content/uploads/2011/09/IR-Discussion-Paper-2011_spreads.pdf. p. 3 [access: 24.09.2014]. 
tion - indeed, the aim is to integrate SASB standards into the standard annual report required by the U.S. Securities and Exchange Commission for all publicly traded companies. The SASB has developed its Sustainable Industry Classification System that categorises ten sectors and 88 industries and has so far issued a Conceptual Framework and nine industry-specific reporting standards (with a tenth under development). Apart from non-financial reporting, accounting standards and key performance indicators, the SASB is also developing a more consistent approach to the use of materiality in sustainability reporting. ${ }^{14}$

The European Federation of Financial Analysts Societies has published key performance indicators for CSR since 2010. The objective of these key performance indicators is to provide a basis for the integration of CSR data into corporate performance reporting. The current release (key performance indicators for ESG version 3.0) sets out the overall requirements for CSR reports, guidelines for presentation and structure, and minimum requirements for the content to be disclosed. They apply to profit-oriented entities. While the framework is suitable for all entities regardless of size, scope and legal form, it has been specifically designed for publicly-listed companies and issuers of bonds. EFFAS encourages investors, financial analysts, credit rating agencies, and other functions vital in capital markets to integrate their key performance indicators into their valuation models. ${ }^{15}$

The AccountAbilty principles for sustainable development were initially published in 1999 and have since undergone various modifications. The current standard in place is the AA1000 Accountability Principles Standard 2008 (AA1000APS), which provides undertakings with a set of principles to frame and structure the way in which they understand, govern, administer, implement, evaluate, and communicate their accountability. The value of the principles of AA1000APS (namely, inclusivity, materiality, and responsiveness) lies in their comprehensive coverage and the flexibility of their application. Accompanying AA1000APS is AA1000AS - a high-level principles-based assurance standard that emphasises the importance of materiality, completeness, and responsiveness. ${ }^{16}$ ISO 26000 is a voluntary CSR standard designed to help undertakings to behave responsibly and to improve their CSR engagement through time. The standard revolves around Seven Core Subjects: organisational governance, human rights, labour practices, environment, fair operating practices, consumer issues and community involvement and development. One of the ISO 26000's core objectives is to improve the reliability of undertakings' communication and transparency. ${ }^{17}$

14 EU Directive on disclosure, op cit. p. 7.

15 EU Directive on disclosure, op. cit., p. 8.

16 Accountability Principles Standard, AccountAbility, http://www.accountability.org/standards/ aa1000aps.html, [access: 14.08.2017].

17 ISO Standards are international in nature, and developed on the basis of principles established by the World Trade Organisation (WTO) Committee on Technical Barriers to Trade (TBT). These principles relate to the way in which an international standard development process is 


\section{Non-Financial Reporting Under EU Directives}

The European Union's policy in the field of disclosure of non-financial information has been practically reflected in the European Commission's "Green Paper: Promoting framework for Corporate Social Responsibility", published in 2001..$^{18}$ The Green Paper, which is subject to regulation by the $\mathrm{EC}$, contains internal and external non-financial issues which primarily concern CSR problems. In 2011 the EU formulated a plan for the development of good practices in the area of reporting of environmental and social issues in the Member States "European Commission Communication on CSR 2011: Implementation table".$^{19}$ One of the objectives of the adopted plan was to improve the quality of reporting of environmental and social issues.

A very important step in the subject of non-financial reporting was the adoption in 2013 of Directive 2013/34 / EU, which concerns the disclosure of information on environmental issues, social and employment issues, including the protection of human rights, anti-fraud and corruption, respecting the principles of diversity management. Directive 2013/34 / EU provides for the obligation of reporting information related to large enterprises of public interest, i.e. quoted companies, insurance companies, banks and other organisations of public importance in view of their business profile and their employing more than 500 staff on average in a financial year as at the balance closing date, in the form chosen by the company, i.e. either in the annual financial report or in a separate report. Non-financial reports are to be drawn up with respect for the principle of comply or explain, meaning the need to explain the reasons for the non-disclosure of certain information.

Directive 2013/34/EU concerning the disclosure of non-financial and diversity information by certain large undertakings and groups was amended by the Directive 2014/95/ EU. According to Art. 1 section 1 item 1 of the EU Directive, the organisations concerned shall include in their reports non-financial information, including information required to understand the development, results and position of the organisation and the impact of its operations in respect of environmental and social issues, respect for human rights, counteracting bribery and corruption, including as a minimum:

carried out, and include expectations of transparency, openness, impartiality and consensus, effectiveness and relevance, coherence, and addressing the needs of developing countries. These are further complemented by the disciplines of Annex 3 of the WTO TBT agreement- Code of Good Practice for the preparation, adoption and application of standards - a Code which ISO national members are encouraged to comply with. (ISO 26000 - Social responsibility, http://www.iso.org/iso/home/standards/iso26000.htm, access: 10.05.2014).

18 Green Paper. Promoting a European framework for Corporate Social Responsibility, Commission of the European Communities, Brussels 2001, COM (2001) 366 final.

19 European Commission Communication on CSR 2011: Implementation table, Ec.europa.eu 2011, http://ec.europa.eu/enterprise/policies/sustainable-business/files/doc/csractionstimeline121213webversion_en.pdf [access: 28.05.2014]. 
- a brief description of the undertaking's business model,

- a description of the policies pursued by the undertaking in relation to those matters, including due diligence processes implemented,

- the outcome of those policies,

- the principal risks related to those matters linked to the undertaking's operations including, where relevant and proportionate, its business relationships, products or services which are likely to cause adverse impacts in those areas, and how the undertaking manages those risks,

- non-financial key performance indicators relevant to the particular business.

- Pursuant to the preamble to Directive 2014/95UE, the report should disclose:

- environmental matters (e.g. health and safety, use of renewable and/or non-renewable energy, greenhouse gas emissions, water use and air pollution),

- social and employee-related matters (e.g. gender equality, implementation of fundamental conventions of the International Labour Organization, working conditions, social dialogue, respect for the right of workers to be informed and consulted, respect for trade union rights, health and safety at work and the dialogue with local communities, and/or the actions taken to ensure the protection and the development of those communities),

- human rights matters (e.g. information on the prevention of human rights abuses), anti-corruption and bribery matters (e.g. information on the instruments in place to fight corruption and bribery).

Such statements should include a description of the policies, outcomes and risks related to those matters and should be included in the management report of the undertaking concerned. The non-financial statement should also include information on the due diligence processes implemented by the undertaking, also regarding, where relevant and proportionate, its supply and subcontracting chains, in order to identify, prevent and mitigate existing and potential adverse impacts. Reporting organisations must, as a minimum, provide explanations if they do not follow any policies in respect of the foregoing issues. By way of exception, they may omit information about expected occurrences or matters subject to negotiations in progress if their disclosure might have a seriously adverse effect on the commercial position of the organisation, while having no impact on the correct and objective understanding of the development, performance and position of the organisation and the impacts of its activities. The company may be free from the duty to report non-financial information if they prepare a separate report which is published together with financial statements, or on the organisation's website, within six months of the balance closing date, and if financial statements contain a reference to such a report. There is significant flexibility for companies to disclose relevant information (including reporting in a separate report), and they may rely on international, Eu- 
ropean or national guidelines (e.g. the Eco-Management and Audit Scheme (EMAS) ${ }^{20}$, the UN Global Compact, the OECD Guidelines for Multinational Enterprises, ISO 26000 , etc.).

\section{Guidelines on Disclosure of Non-Financial Information}

The European Commission published the Guidelines to the Directive 2014/95UE on 26 June 2017 to support companies in the preparation of this non-financial statement. ${ }^{21}$ The guidelines do not add any legal requirements to the non-financial reporting directive. They do not prescribe reporting guidelines or standards, but they do recommend a few of them, such as the UN Guiding Principles on Business and Human Rights or ISO 26000. They also take into account the UN COP21 Paris Climate Agreement, ${ }^{22}$ with the disclosure of information on the actual and potential impacts of the organisation's activities on the environment, especially regarding the reduction of greenhouse gas emissions.

The Guidelines set out the purpose of this disclosure. The aim of these guidelines is to help companies disclose high quality, relevant, useful, consistent and more comparable non-financial (environmental, social and governance-related) information in a way that fosters resilient and sustainable growth and employment, and provides transparency to stakeholders. These non-binding guidelines are proposed within the remit of the reporting requirements provided for under the Directive. They are intended to help companies draw up relevant, useful concise non-financial statements according to the requirements of the Directive.

These guidelines put the emphasis on relevant, useful and comparable non-financial information in accordance with Article 2 of Directive 2014/95/EU.

The guidance is addressed to the companies required by the Directive to disclose nonfinancial information in their management report. However, the non-binding guidelines could represent best practice for all companies that disclose non-financial information, including other companies not included in the scope of the Directive. The European Commission has prepared the guidelines to develop a principle-based methodology relevant to companies across all economic sectors, which helps them disclose relevant, useful and comparable non-financial information. These guidelines are framed in the con-

20 EMAS (Eco Management and Audit Scheme) is an EU environmental protection instrument based on: Regulation (EC) No 1221/2009 of the European Parliament and of the Council of 25 November 2009 on the voluntary participation of organizations in the eco-management and audit system in the Community (EMAS), repealing Regulation (EC) No 761/2001 and Commission Decisions 2001/681 / EC and 2006/193 / EC, Official Journal of the European Union L 342/1.

21 Guidelines on non-financial..., op. cit.

22 Paris Agreement, United Nations 2015, https://unfccc.int/files/essential_background/convention/application/pdf/english_paris_agreement.pdf [access: 12.08.2017]. 
text of the management report. The intent is to provide balanced and flexible guidance on the reporting of non-financial information in a way that helps companies disclose material information consistently and coherently. The guidelines recognise the importance of linkages and inter-relations of information (connectivity), whether it is between different aspects of non-financial information or between financial and non-financial information. As much as possible, these Guidelines should help ensure comparability across companies and sectors. This approach recognises the broad diversity of the businesses and sectors involved, and of the circumstances that companies need to reflect in their reporting. Significant efforts have been made to avoid a 'one-size-fits-all' approach and an overly prescriptive methodology.

The guidelines set out the basic principles of disclosing non-financial information. These principles result from the basic assumption that the management report shall include a non-financial statement containing information to the extent necessary for an understanding of the undertaking's development, performance, position and impact of its activity (3.1 point of the Guidelines). It is assumed that Materiality is a concept already commonly used by preparers, auditors and users of financial information. A company's thorough understanding of the key components of its value chain helps identify key issues, and assess what makes information material. Companies may report on a wide range of potential issues. A company assesses which information is material based on its analysis of how important that information is in understanding its development, performance, position and impact. This materiality assessment should take into account internal and external factors. A number of factors may be taken into account when assessing the materiality of information. These include:

- Business model, strategy and principal risks. (The company's goals, strategies, management approach and systems, values, tangible and intangible assets, value chain and principal risks are relevant considerations).

- Main sectoral issues. (Similar issues are likely to be material to companies operating in the same sector, or sharing supply chains. Topics already identified by competitors, customers or suppliers are likely to be relevant for a company).

- Interests and expectations of relevant stakeholders. (Companies are expected to engage with relevant stakeholders and seek a good understanding of their interests and concerns).

- Impact of the activities. (Companies are expected to consider the actual and potential severity and frequency of impacts. This includes the impacts of their products, services, and their business relationships, including supply chain aspects).

- Public policy and regulatory drivers. (Public policies and regulation may have an effect on the specific circumstances of a company, and may influence materiality).

The Guidelines require that non-financial statements should give fair consideration to favourable and unfavourable aspects, and information should be assessed and pre- 
sented in an unbiased way (3.2 point of the Guidelines). Therefore, it should consider all available and reliable inputs, taking into account the information needs of relevant stakeholders. Users of information should not be misled by material misstatements, by omitting material information, or disclosing immaterial information. It is emphasized that Material information on certain categories of issues explicitly reflected in the Directive should be disclosed as a minimum. These include:

- environmental, social and employee matters;

- respect for human rights;

- anti-corruption and bribery matters (3.3 point of the Guidelines).

It is assumed that non-financial information will allow insights into a company's business model, strategy and its implementation to be provided, and explain the short-term, medium-term and long-term implications of the information reported. By disclosing targets, benchmarks and commitments, a company may help investors and other stakeholders to put its performance in context. This may be helpful when assessing future prospects. The external monitoring of commitments and progress towards targets promotes greater transparency towards stakeholders. Targets and benchmarks may be presented in qualitative or quantitative terms. As appropriate, companies may disclose relevant information based on science-based scenarios (3.4 point of the Guidelines).

The Guidelines are expected to be consistent with other elements of the management report. The content of the non-financial report should be consistent over time. This enables users of information to understand and compare past and present changes in a company's development, position, performance and impact, and relate reliably to forward-looking information. Consistency in the choice and methodology of key performance indicators is important to ensure that the non-financial statement is understandable and reliable. However, updates may be necessary, as key performance indicators may become obsolete, or new and better methodologies be developed that improve the quality of information. Companies are expected to explain any changes in reporting policy or methodology, the reasons for changing them and their effects (for example by restating past information, clearly showing the effect of changing reporting policies or methodologies) (3.6 point of the Guidelines).

Important non-financial information that should be disclosed is the diversity policy, which shall be included in their corporate governance statement. The description of the board diversity policy does not form part of the non-financial statement. Therefore, this section of the guidelines is without prejudice to the need to disclose material diversity information as part of the non-financial statement (6 point of the Guidelines). Article 1 of the Directive 2014/95/EU requires large listed companies to disclose in their corporate governance statement: "a description of the diversity policy applied in relation to the undertaking's administrative, management and supervisory bodies with regard to aspects such as, for instance, age, gender, or educational and professional backgrounds, 
the objectives of that diversity policy, how it has been implemented and the results in the reporting period. If no such policy is applied, the statement shall contain an explanation as to why this is the case". The description of the diversity policy should specify which diversity criteria are applied and explain the reasons for choosing them. When selecting these criteria, all relevant diversity aspects should be considered to ensure that the board has a sufficient diversity of views and the expertise needed for a good understanding of current affairs and longer-term risks and opportunities related to the company's business. The nature and complexity of the company's business should be taken into account when assessing the profiles needed for optimal board diversity, as should the social and environmental context in which the company operates. The diversity aspects should, in general, cover age, gender, or educational and professional backgrounds. Where relevant due to the company's geographical presence and the business sector in which it operates, it is also appropriate to include geographical provenance, international experience, expertise in relevant sustainability matters, employee representation and other aspects, for example the socioeconomic background.

It seems that the requirements imposed on the non-financial statements by the Guidelines are as justified as possible. It is obvious that the condition for the proper fulfillment of the non-financial reporting of its tasks is that the information is presented in an orderly, fair and useful manner. The information presented in the non-financial statements should be understandable to users with a certain level of knowledge of business. The comprehensibility of information is ensured when it is presented transparently and clearly. However, this does not mean that information that can be difficult to understand for the average user may be omitted in the non-financial statements, if it is relevant in or for the decision making. Reporting information is useful when it has the ability to influence the economic decisions of users. The usefulness of the information depends on its other characteristics, namely - relevance. Information is relevant if it can affect the evaluation of the business processes in the company and improve the quality of the forecasts made by the user of the financial statements. The requirement that information be relevant is achieved by simplifying the registration issues that are irrelevant from the point of view of the decisions to me made.

\section{Conclusions}

The need to standardise non-financial reporting to ensure its transparency and clarity is noted by researchers and reporting organisations. In their opinion, the reports should be clear, transparent and comparable and stakeholders should be able to fully satisfy their information requirements. This is also evidence of the care taken over ensuring good relations with stakeholders, who receive standardised data. The regulations of Di- 
rective 2014/95 / U, are a step forward, since they will help to standardise the rules of reporting non-financial information, and will improve its transparency and utility. Lack of detailed regulations would impede their comparability, since organisations could rely on different rules and guidelines. Thus, this Directive fills a regulatory gap and improves the usefulness of the information generated by organisations obliged to prepare nonfinancial reports. This Directive demonstrates the commitment of the European Union to advance corporate transparency and sustainability - supporting smart, sustainable and inclusive growth, and paving the way for a sustainable global economy. It is a kind of a new "paradigm" in enterprise reporting.$^{23}$

Mandatory reporting laws do not introduce any binding mandates on companies to limit environmental pollution, increase labour standards or introduce quotas for female representation on corporate boards. The emphasis is still clearly on voluntary action such as stakeholder engagement, transparency and learning through the development of best practice and the common norms of responsibility. In most cases, the non-financial reporting has not yet reached the quality used for financial reporting. This weakness is related to, inter alia, the problem of measurement issues covered by non-financial reporting and the scope of the disclosed information.

Because the reporting system should take into account the reporting information the users actually demand, and provide the set of information needed in the modern market economy, it is accepted that a balanced approach to financial and non-financial information provides a more complete picture that enables investors and other stakeholders to better understand how company value is created and managed. This view is also shared by the EU, which says that more transparency will drive the long-term performance of the EU's largest companies and contribute to Europe's competitiveness and the creation of more jobs. The fact that the Directive is limited to large corporations and draws on a variety of existing codes, which tend to emphasise environmental over social issues means that any positive change will be limited, however. Nevertheless, there is agreement that transparency leads to better performance. All companies that disclose information on social and environmental matters reap significant benefits over time. Companies that use these guidelines will be able to better integrate material environmental and social information in their business cycle, innovate and adapt their reporting to the particular circumstances of their business, and further rely as appropriate on other reporting frameworks. The first results of the impact the Directive showed in particular that such benefits included lower funding costs, stronger consumer loyalty, and better relations with stakeholders. There is a consensus that well-informed business and investment decisions have much better chances to succeed. Investors, lenders and other stakeholders will benefit from a more informed and efficient decision process.

23 B. Spießhofer, R. G. Eccles, Information und Transformation - CSR - Berichterstattung in Europa und den USA, in: Forum Wirtschaftsethik,Jahresschrift des DNWE, 2014. 
It also seems that society on the whole will benefit from companies managing environmental and social challenges in a more effective and accountable way. The guidelines will support companies in this process. They are principle-based to help companies across all sectors and are designed to be practical, business-oriented and impact-driven. New UE guidelines reflect current best practices and most recent developments at international level, including lessons from the UN Sustainable Development Goals and the Paris Climate Agreement.

\section{Literature}

Accountability Principles Standard, AccountAbility, http://www.accountability.org/standards/aa1000aps.html, [access: 14.08.2017].

COM (2001) 366 final, Green Paper. Promoting a European framework for Corporate Social Responsibility, Commission of the European Communities, Brussels.

EUDirective on disclosure of non-financial and diversity information. Achieving good quality and consistent reporting. Position Paper, Federation of European Accountants, march 2016.

European Commission Communication on CSR 2011: Implementation table, Ec.europa.eu 2011.

http://ec.europa.eu/enterprise/policies/sustainable-business/files/doc/csractionstimeline121213webversion_en.pdf, [access: 28.05.2014].

Financial vs Non-Financial Information, Materialitytracker, 2016, http://www.materialitytracker.net/standards/financial-vs-non-financial-information/, [access: 20.01.2016].

Green Paper. Promoting a European framework for Corporate Social Responsibility, Commission of the European Communities, Brussels 2001, COM (2001) 366 final.

G4 Sustainability Reporting Guidelines, Implementation Manual, Global Reporting Initiative, https://www.globalreporting.org/resourcelibrary/GRIG4-Part2-Implementation-Manual.pdf [access: 2.03.2015].

G4 Sustainability Reporting Guidelines, Reporting Principles and Standard Disclosures, Global Reporting Initiative, https://www.globalreporting.org/resourcelibrary/GRIG4-Part1-Reporting-Principles-and-Standard-Disclosures.pdf [access: 2.03.2015].

ISO 26000 - Social responsibility, http://www.iso.org/iso/home/standards/iso26000.htm, [available in 10 May 2014].

Non-financial information in progress. A guide to the reporting and assurance of non-financial information in the public sector, Nivra, 008 Royal NIVRA Amsterdam, https://www. nba.nl/Documents/Vaktechnisch-thema/MVO/NFI-wegwijzer-Engelse-versie.pdf [ available: 2 January 2016]. 
OECD Guidelines for Multinational Enterprises 2011 Edition, OECD Publishing, 2011. EU Directive on disclosure.

Official Journal of the European Union L 182/19 2013. Directive 2013/34/EU of The European Parliament and of The Council of 26 June 2013 on the annual financial statements, consolidated financial statements and related reports of certain types of undertakings, amending Directive 2006/43/EC of the European Parliament and of the Council and repealing Council Directives 78/660/EEC and 83/349/EEC.

Official Journal of the European Union, L 330/1 2014. Directive 2014/95/EU of The European Parliament and of the Council of 22 October 2014 amending Directive 2013/34/EU as regards disclosure of non-financial and diversity information by certain large undertakings and groups.

Paris Agreement, United Nations 2015, https://unfccc.int/files/essential_background/ convention/application/pdf/english_paris_agreement.pdf [access: 12.08.2017].

Perrin F., The Practitioner's Perspective on Non-Financial Reporting, California Management Review, vol. 48, no. 2, Winter 2006, pp. 75-78.

Regulation (EC) No 1221/2009 of the European Parliament and of the Council of 25 November 2009 on the voluntary participation of organizations in the eco-management and audit system in the Community (EMAS), repealing Regulation (EC) No 761/2001 and Commission Decisions 2001/681 / EC and 2006/193 / EC, Official Journal of the European Union L 342/1.

Spießhofer B, Eccles R.G., Information und Transformation-CSR-Berichterstattung in Europa und den USA, in: Forum Wirtschaftsethik, Jabresschrift des DNWE, 2014.

The International $<I R>$ Framework, Integrated Reporting $(<\mathrm{IR}>)$, IIRC, http://www. theiirc.org/wp-content/uploads/2013/12/13-12-08-THE-INTERNATIONAL-IRFRAMEWORK-2-1.pdf [access: 23.09.2014].

The road to reliable nonfinancial reporting, Ernst\&Young, 2016, http://www.ey.com/Publication/vwLUAssets/EY-ccass-road-to-reliable-nonfinancial-reporting/\$FILE/EYccass-road-to-reliable-nonfinancial-reporting.pdf [access: 4.11.2016].

The Tenprinciples, United Nations Global Compact, https:/www.unglobalcompact.org/ aboutthegc/.[access: 20.01.2014].

Towards Integrated Reporting. Communicating Value in the 21st Century, IIRC, http:// theiirc.org/wp-content/uploads/2011/09/IR-Discussion-Paper-2011_spreads.pdf. p. 3, [access: 24.09.2014].

Tripartite declaration of principles concerning multinational enterprises and social policy, International Labour Office, Geneva 2006. 
184 | Adam Mickiewicz University Law Review

SUMMARY

\section{Non-Financial Reporting in the Light of International Regulations and EU Directives}

The need to standardise non-financial reporting to ensure its transparency and clarity is noted by researchers and reporting organisations. In their opinion, the reports should be clear, transparent and comparable and stakeholders should be able to fully satisfy their information requirements. Bearing in mind this assumptions the aim of the study is to analyse the non-Financial reporting system within the scope of international and European Union law. The author pays attention to the essence of reporting non-financial Information and its standards, EU Directives and Guidelines of Discolure.

Keywords: Reporting Non-Financial Information, international law, EU law

Ryszard Kamiński, Adam Mickiewicz University Poznań, Faculty of Law and Administration, A1. Niepodległości 53,61-714 Poznań, Republic of Poland, e-mail: ryszard.kaminski@amu.edu.pl. 